\title{
光電池に依る音響强度の測定法に就て
}

\author{
正會員 門 倉 則 之 \\ 佐 藤 武 夫
}

(早稻田大學現工學部)

\section{The Measurement of Sound Intensities by Using Photo-Electric Cell.}

N. Kadokura, Member

T. Satow

(Waseda University)

\section{內 容 梗 概}

本文は光電池の剐用の一つを示したるおのであ る。

建築物內に於ける音響强度の現象を研究する場合 に，光を使用する方法は種々あるが，何れる數量的
に其の結果を得る事は出來ぬものである。光電池を 用ひて之を行ふ場合には簡單に反射の狀態を數量的 に求むる事が出來る。且つ其の場合に欲する反射率 を有する反射を作りて研究爫す事が出來る。

\section{Synopsis}

The paper describes results of measurement of reflected sounds in model buildings with a photo-eleciric cell. By this method, it is possible

緒 to obtain quantitative measurements of reflections in models with such materials of the same reflection coefficients as in actual cases.

需

光波及び音波は二種の異なりたる媒質の境界面に澾したる場合は反射，吸收及び透過の諸現象 を呈する。

音波は光波に比して其の波長は一般に極めて大なるるのであるからして光波に對して橆反射を 雹すが如き面に對しても正反射を雼すものである。ての場合の法則等も兩者に對して全々同一の 形式をとるものである。

講堂, 劇場等の大建築物に於ては其の天井, 側壁及び後壁等の音響の反射を利用する事極めて 大なるものである。是等の建物內に於て聽衆の㯖く音は, 發音體よりの直接の音と天井, 側壁及 び後壁等よりの反射し來りたる音との總和である。ての反射し來る亘の强度は天井, 側壁等の形 爿によりて異なる事刎論であるが，是等のものの面の材料つ吸音率にも極めて關係深をものであ る。

郎ち反射力大なる場合は餘響（Reverberation）は過大となり明膫に音を聽く事が困難である。 又逆に反射力小方る場合は直接音のみとなり，屋外に於ける場合と選ぶ事無きに至るは篦知の事 實である。

各種の建築物に使用する材料の吸豆率を示すと第一表の如くである。 
第 一 表

Sound Absorbing Coefficients for Pitch 512

Material

Coeff per sq. ft.

$\begin{array}{llll}\text { Open Window } & 1.00 & \text { Flaxlinum, bare, 1 in thick. } & 0.61 \\ \text { Brick Wall } & 0.032 & \text { Glass (single thickness) } & 0.027 \\ \text { Calacoustic Plaster } & 0.16 & \text { Hairfelt, bare, 1 in. thick. } & 0.58 \\ \text { Carpet, lincd } & 020 & \text { Linoleum } & 0.03 \\ \text { Carpet rugs } & 0.20 & \text { Marble } & 0.01 \\ \text { Acousti-Celotex, type A } & 0.25 & \text { Plaster on lath (wood) } & 0.034 \\ \text { Acousti-Celotex, type B } & 0.47 & \text { Plaster on tile } & 0.025 \\ \text { Armstrong Cork Board, } 1 \text { in. thick. } 0.30 & \text { Wood, Plain } & 0.06 \\ \text { Cork tile } & 0.03 & \text { Wood, Varnished } & 0.03 \\ \text { Curtains in heavy folds } & 0.40-0.75 & & \end{array}$

"The Absorption of Sound by Matcrials" By Flcyd R. Watson"

(Univ. of Illinois Bulletin, Vol. XXV, No. 13) Bulletin No. 172. より萃拢

而して既設の建築物に於て，其の坐席に於ける音の强度等を實地に测定する事は困難である。 故に設計する場合には圖面上に於て，其の反射の方向を各面に對して求め其の反射の狀態を豫 测嘕すか，又は模型を作りて，てれを行ふものである。

模型に依る方法は各種ある。

(1) 磁音衝擊汒 (Sound-pulse Method) (1)

てのカ法は適當なる大いさの测定せんとする断面を作り, 其の發曋部に相當䉆す所で蓄電器放 電を行はしめて音を發生し，故百秒分の一荱れて，光を發せしめて，其の空氣の波を乾板に撮影 せしむるものである。

(2) 㵀槽法 (Ripple-tank Method) (2)

てれは, 底面に硝子板を張りたる器に水を入れ, 所要斷面の枠を入れて, 器の上方又は下方よ り光を投じて，水波の反射の狀態を测定するものである。

(3) 光に位る方法 (3)

てれは鏡的反射を爲す金屬板にて，模型を作り發曋部に光源を設け，其の各部に於ける反射光 線の方向を小忹の蔭の方向にょりて测定霞すものでする。

是等何れの方法沉於ても，數量的に装の值を求むる事の出來ざるものであり，且つ其の测定面 の反射率 (1-吸音率) を變化せしむる事は全々不可能つ事である。

(1) Arthur L. Foley and Wilmer H. Sounder :- A New Method of Photographing Sound Waves. (Physical Review, 35. p. 373. 1912)

(2) A.H. Davis \& G. W. C. Kaye:- The Acoustics of Buildings, 1927, page 55.

(3) R. F. Norris :-

A New Way of Petermine Echoes. (Arch. Forum. Part two, May 1928) 
光電池法は第三の場合と同じく模型は鏡的反射面を有する金屬板にて作り，發音部に光源を置 を各位置に於ける光電電流をガルバノメーターを用ひて测定篇したるものである。斯く雼す事に よりて明らかに其の反射の狀態を數量的に測定䉆す事が出來, 且つ又其の反射率は, サポンエナ メル (Zapon Enamel) を鏡的反射を有する金屬面に塗る事によりて任意のものを作る事が出來 得るのである。

てれによりて鏡的反射を爲し且つェナメルの色柇又は其の濃度を加減する事によりて如何なる 反射率を有するものをも作り得るのである。故に模型によりて音の反射狀態を正確に知る事が出 來るのでする。

\section{實驗}

先づ二三の金屬板に對して, 光電池を用 ひて其の反射光線を测定爲した。其の配列 は第一圖の如くである。

$S$ は光源の位置を示し，光源としては

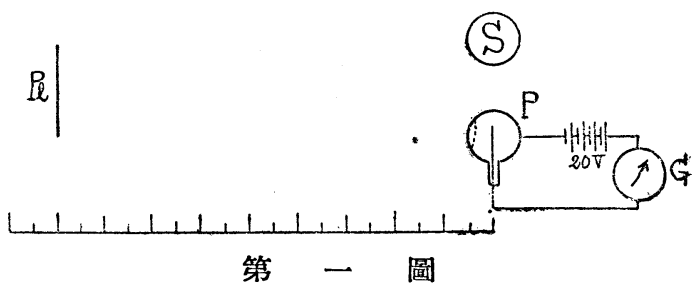
100 V. 200 c.p の交流タングステン弧光燈を使用した。Pl は測定せんとする金蛬板，P は光電池 の位置でする。ての場合使用第したる光電池は第二洄の如きものである。

第一圖の如を裝置にて，約 10 糎 $\times 10$ 糎のアルミニウーム板，真鍮板及び銅板を $P l$ の位置に 置を，其の光源に對する位置を變じて反射光線を光電池及びガルバノメーターで测定篇した。其 の結果は第二表及び第三圖の如くである。

$$
\text { 第 二 裴 }
$$

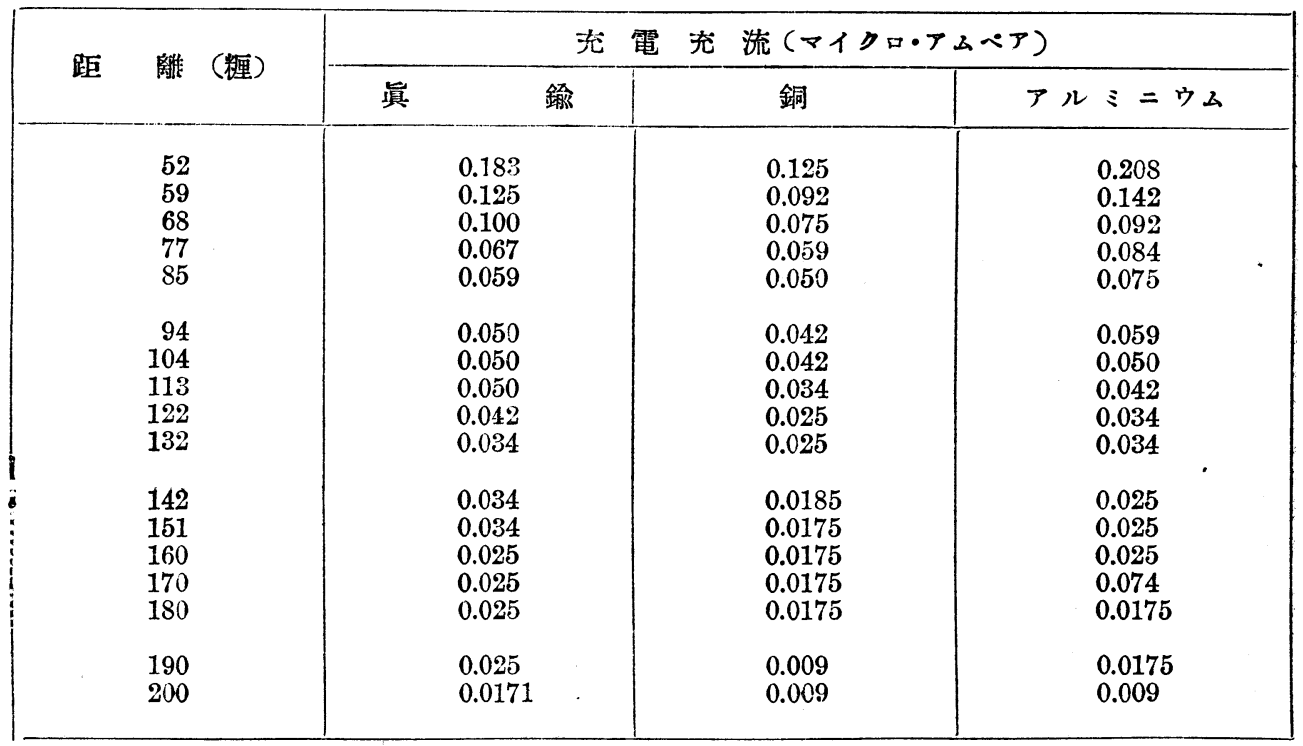

第三圖の結果よりして，アルミニウーム板を使用して模型を作る事と䉆し，アルミニウム板 の反射率を 100 パーヒントと假定し，種々の反射率を有する板を作る䉆めに第二表に示した場合 こ同種のアルミニウム板 (原さ約 20 ミル) を 10 糎 $\times 10$ 糎の大いさに切斷第し，てれに浱淡各 


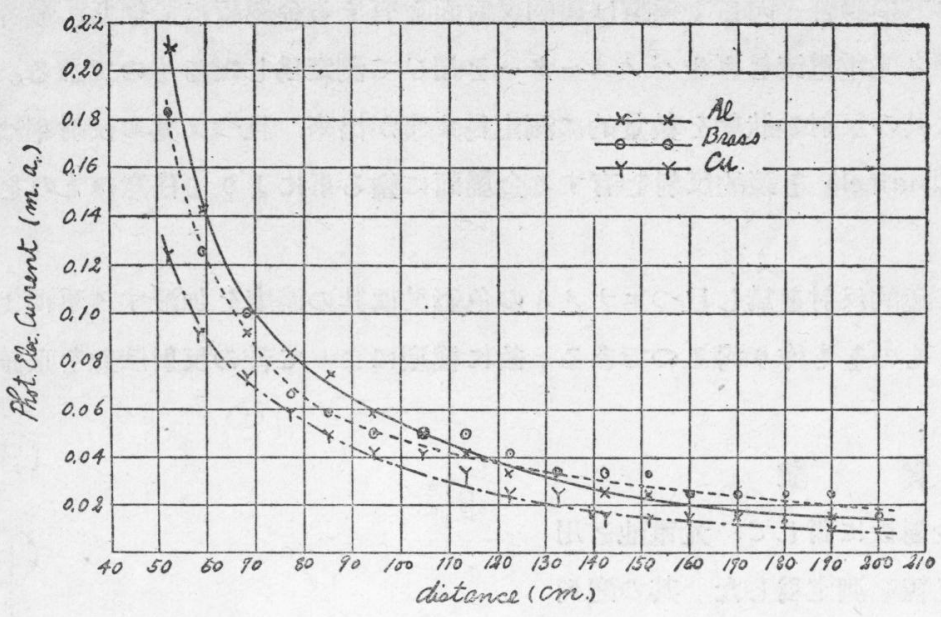

第 三 圖

種の黃色ザポンエナヌルを一樣に塗り，度一圖と同じ裝置を用ひて其の各々の板の反射光線を測 定営した結果第三表及び第四圆の如きものを得た。

第 三 表

\begin{tabular}{|c|c|c|c|c|c|c|}
\hline \multirow{2}{*}{ 距 } & \multirow{2}{*}{ 離 (㯵) } & \multicolumn{5}{|c|}{ 光 電 電 流(マイクロ・アムペア) } \\
\hline & & $R_{0}$ & $R_{1}$ & $R_{2}$ & $R_{3}$ & $R_{4}$ \\
\hline & $\begin{array}{l}52 \\
59 \\
68 \\
77 \\
8 \check{5}\end{array}$ & $\begin{array}{l}0.208 \\
0.142 \\
0.092 \\
0.084 \\
0.075\end{array}$ & $\begin{array}{l}0.142 \\
0.117 \\
0.092 \\
0.084 \\
0.059\end{array}$ & $\begin{array}{l}0.122 \\
0.084 \\
0.067 \\
0.050 \\
0.042\end{array}$ & $\begin{array}{l}0.075 \\
0.059 \\
0.042 \\
0.042 \\
0.025\end{array}$ & $\begin{array}{l}0.034 \\
0.0175 \\
0.0175 \\
0.009 \\
0.009\end{array}$ \\
\hline & $\begin{array}{r}94 \\
104 \\
113 \\
122 \\
132\end{array}$ & $\begin{array}{l}0.059 \\
0.050 \\
0.042 \\
0.034 \\
0.034\end{array}$ & $\begin{array}{l}0.050 \\
0.034 \\
0.034 \\
0.025 \\
0.0175\end{array}$ & $\begin{array}{l}0.034 \\
0.0175 \\
0.0175 \\
0.0175 \\
0.009\end{array}$ & $\begin{array}{l}0.025 \\
0.0175 \\
0.009 \\
0.009 \\
0.009\end{array}$ & $\begin{array}{l}0.000 \\
0.000 \\
0.000 \\
0.000 \\
0.000\end{array}$ \\
\hline & $\begin{array}{l}142 \\
151 \\
160 \\
170 \\
180\end{array}$ & $\begin{array}{l}0.025 \\
0.025 \\
0.025 \\
0.0175 \\
0.0175\end{array}$ & $\begin{array}{l}0.0175 \\
0.0175 \\
0.009 \\
0.009 \\
0.009\end{array}$ & $\begin{array}{l}0.009 \\
0.009 \\
0.009 \\
0.009 \\
0.000\end{array}$ & $\begin{array}{l}0.009 \\
0.009 \\
0.009 \\
0.000 \\
0.000\end{array}$ & $\begin{array}{l}0.000 \\
0.000 \\
0.00 \\
0.00 \\
0.00\end{array}$ \\
\hline & $\begin{array}{l}190 \\
200\end{array}$ & $\begin{array}{l}0.0175 \\
0.009\end{array}$ & $\begin{array}{l}0.009 \\
0.00\end{array}$ & $\begin{array}{l}0.000 \\
0.000\end{array}$ & $\begin{array}{l}0.000 \\
0.000\end{array}$ & $\begin{array}{l}0.00 \\
0.00\end{array}$ \\
\hline
\end{tabular}

第三表及び第四圖に於て， $R_{0}$ エナメルを塗らざるアルミニウム板に對する测定值でする。

$R_{0}$ の反射率を 100 パーセントと假定し， $R_{1}, R_{2}, R_{3}$ 及び $R_{4}$ 等の反射率の本均を求されば 次の如きものとなる。

$\begin{array}{llll}R_{0} & 100 \% & R_{3} & 37.2 \\ R_{1} & 77.5 & R_{4} & 12.2 \\ R_{2} & 58.5 & & \end{array}$

アルミニウム板よりの反射光線と, 光源よりの直接光線とは其性質が異なる䉆め, 硝子板に無色 のサポンエナメルを塗りたるものを作りて、スクリーンと篇して直接光線の性質を變化せしめた。 

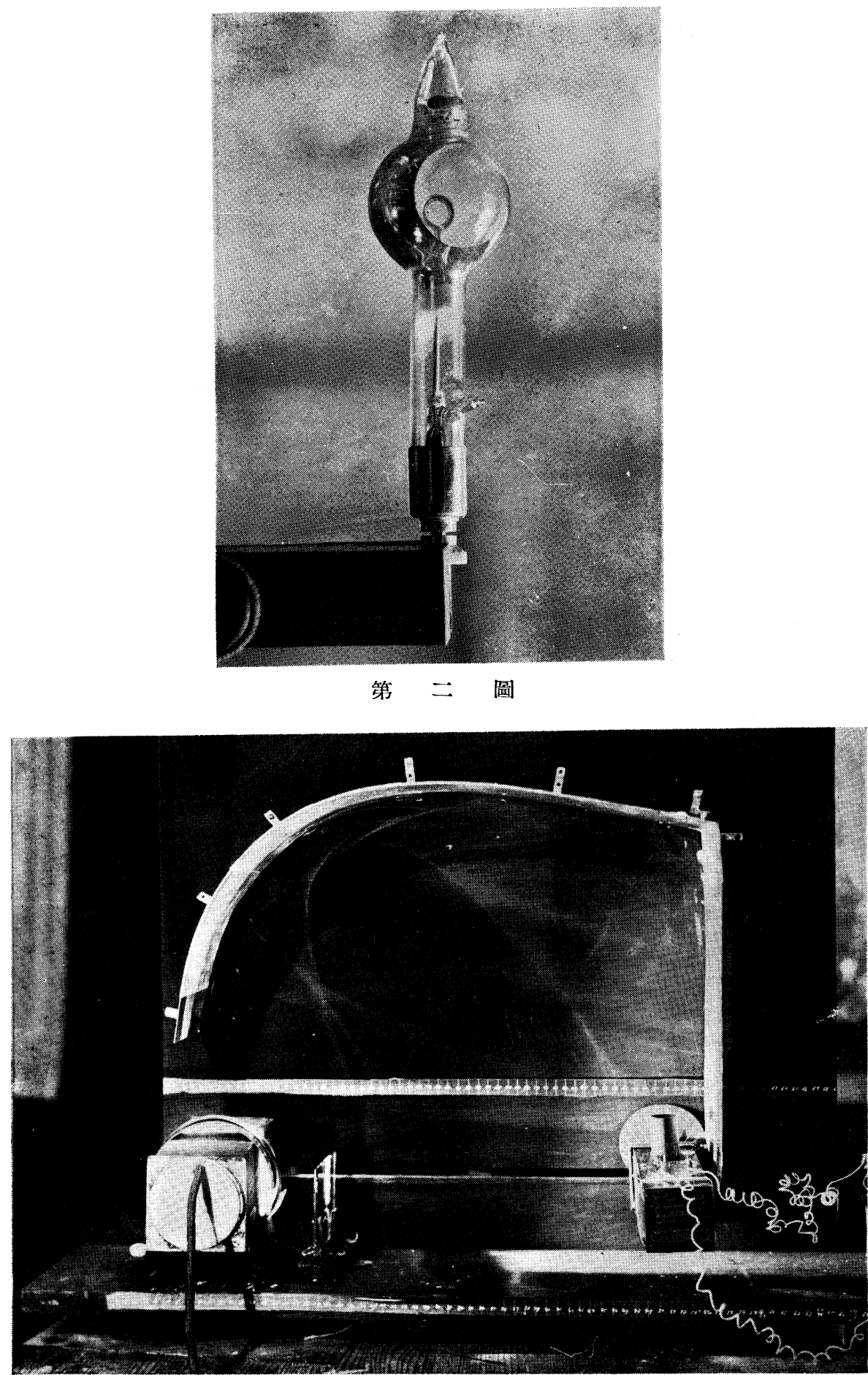

第七圖 


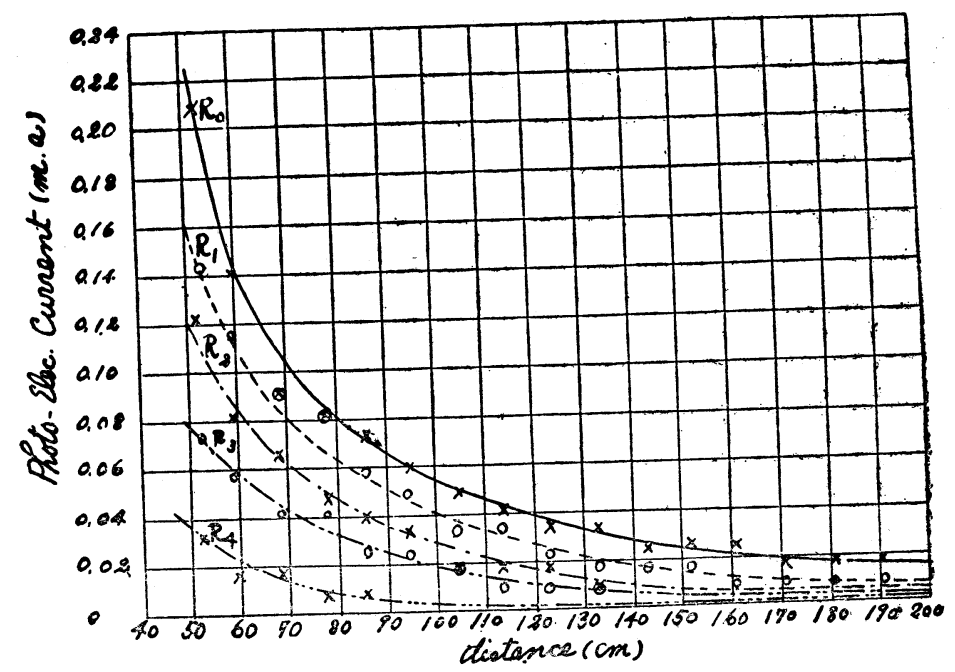

第四圖

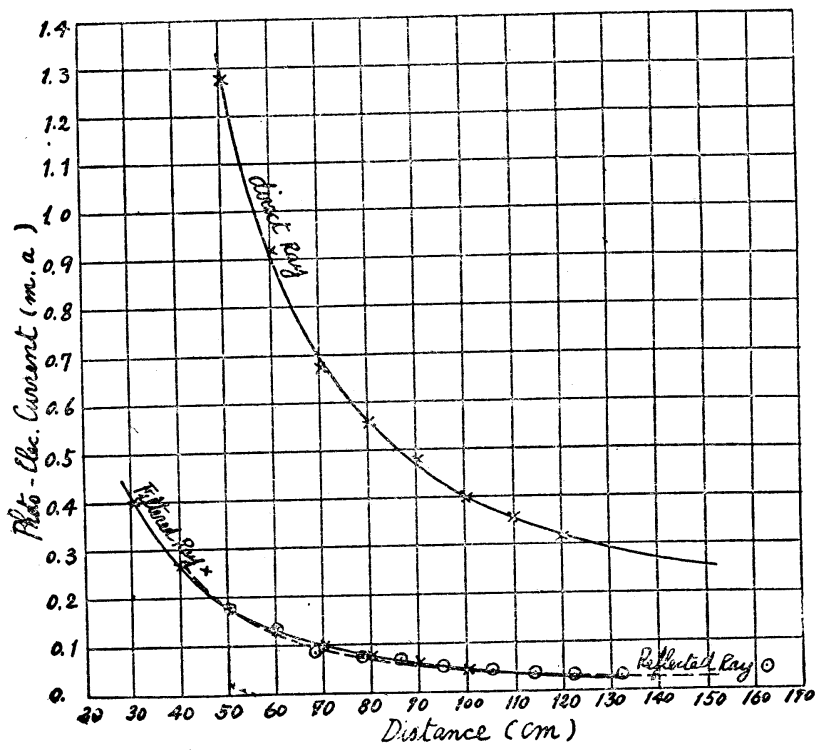

第五圖

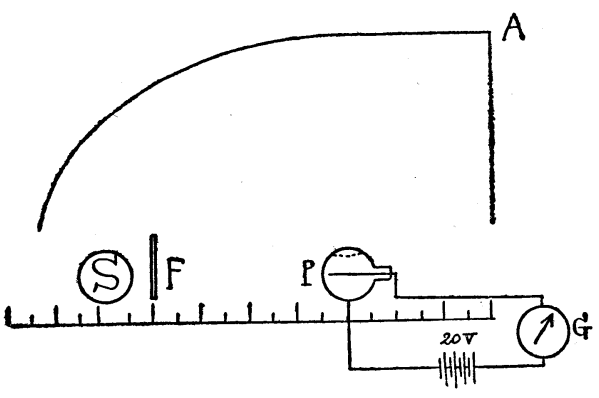

第 六 圖
第五圖は光源よりの直接光線スク リーンを使用して直接光線を滤過し たる場合，及びアルミニウム板の反 射光線等の测定值を示したるもので ある。

模型に對する測定は第六圖の如を 結線で行つたものである。

$A$ は测定せんとする模型であり， $S$ は光源, $F$ はスクリーン, $G$ は ガルバノメーターである。

第七圖は測定䉆したる場合の寫真 を示したものである。 $A$ なる模型は 木製の衝立上に取付けられSの位置 を一定と第し， $P$ の位置を變じて其 の各々の場合の光電電流を測定䉆し たのである又其の各々の位置に於け る反射光線を分析する爲めに，充電 池に直徑 $2.7 \mathrm{~cm}$, 高さ $4.8 \mathrm{~cm}$ の圓 筒を取付け，充電池の力向を，30 度, 70 度, 90 度，110 度，130 祭 に廷轉せしめて，其の光電電流を測 定爲したのである。 
第四表

光電池端子電壓 $20 \mathrm{~V}$. 光源位置 8 糎 電球端子電厴 $100 \mathrm{~V}$

\begin{tabular}{|c|l|c|}
\hline \multirow{2}{*}{ 湘 定 位 置 } & \multicolumn{2}{|c|}{ 電 電 流(マイクロ・アムベア } \\
\cline { 2 - 3 } & $a$ & $b$ \\
\hline 23 糎 & 0.067 & 0.008 \\
28 & 0.0175 & 0.00 \\
33 & 0.008 & 0.00 \\
38 & 0.0175 & 0.008 \\
43 & 0.058 & 0.058 \\
48 & 0.092 & 0.084 \\
52 & 0.505 & 0.505 \\
\hline
\end{tabular}

第四表（續交：

\begin{tabular}{|c|c|c|c|c|c|c|c|c|c|c|}
\hline \multirow{3}{*}{$\begin{array}{c}\text { 测 } \\
\text { 定 } \\
\text { 位 } \\
\text { 角 } \\
\text { 度 } \\
\text { 置 }\end{array}$} & \multicolumn{10}{|c|}{ 充 電 電 流 (マイクロ・アムべ) } \\
\hline & \multicolumn{2}{|c|}{22 框 } & \multicolumn{2}{|c|}{38 栕 } & \multicolumn{2}{|c|}{43 粝 } & \multicolumn{2}{|c|}{48 耀 } & \multicolumn{2}{|c|}{52 糎 } \\
\hline & $a$ & $b$ & $a$ & $b$ & $a$ & $b$ & $a$ & $b$ & $a$ & $b$ \\
\hline 30 & 0.00 & 0.00 & 0.05 & 0.0175 & 0.00 & 0.00 & 0.034 & 0.00 & 0.034 & 0.00 \\
\hline 50 & 0.00 & 0.00 & 0.034 & 0.0175 & 0.00 & 0.00 & 0.00 & 0.00 & 0.265 & 1.82 \\
\hline 70 & 0.008 & 0.00 & 0.008 & 0.00 & 0.00 & 0.00 & 0.115 & 0.0175 & 0.36 & 0.36 \\
\hline 90 & 0.008 & 0.00 & 0.00 & 0.00 & 0.00 & 0.00 & 0.034 & 0.025 & 0.034 & 0.034 \\
\hline 110 & 0.00 & 0.00 & 0.034 & 0.0175 & 0.042 & 0.041 & 0.042 & 0.0175 & 0.15 & 0.117 \\
\hline 130 & 0.025 & 0.025 & 0.067 & 0.034 & 0.034 & 0.025 & 0.05 & 0.0175 & - & - \\
\hline
\end{tabular}

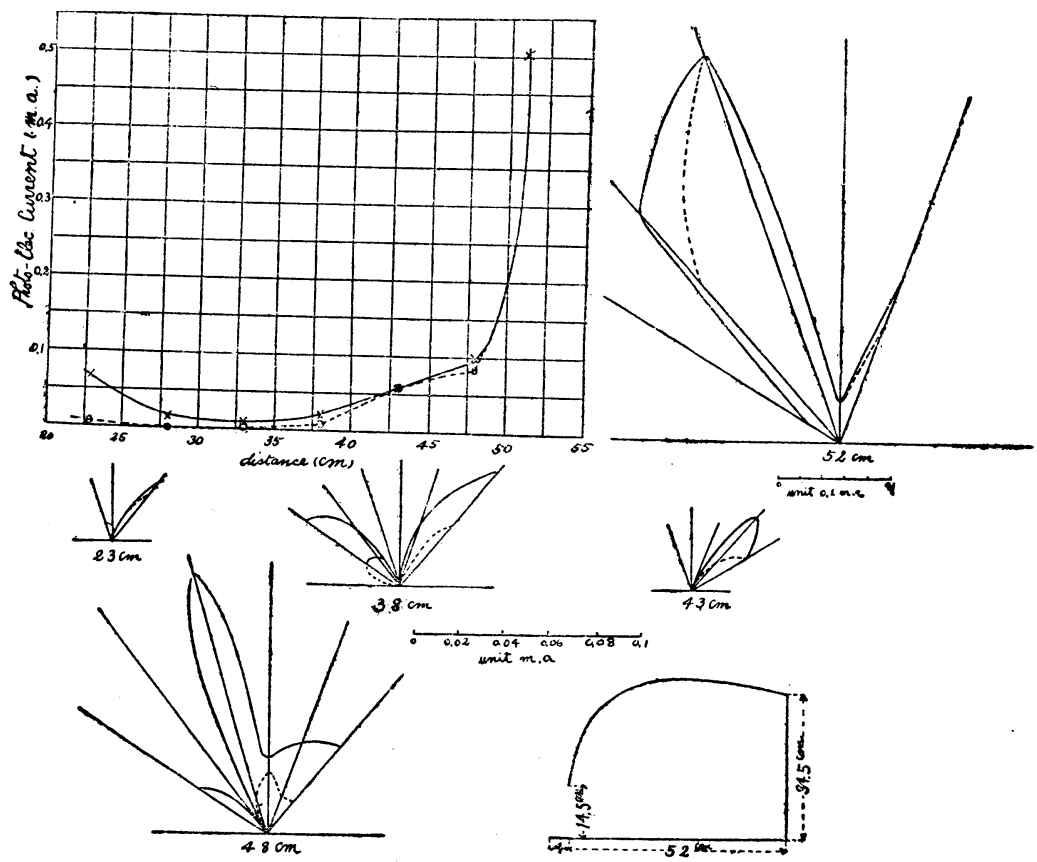

第入 圖 

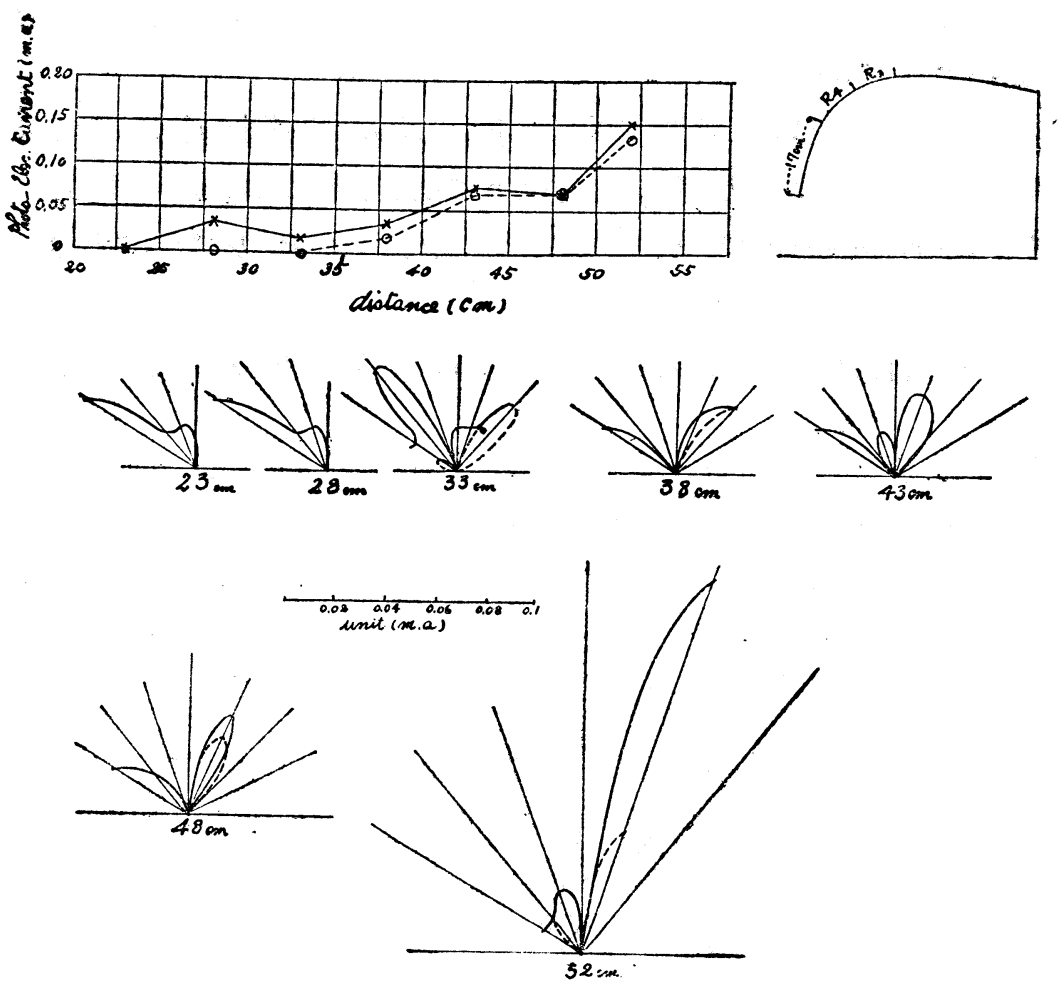

第九圖
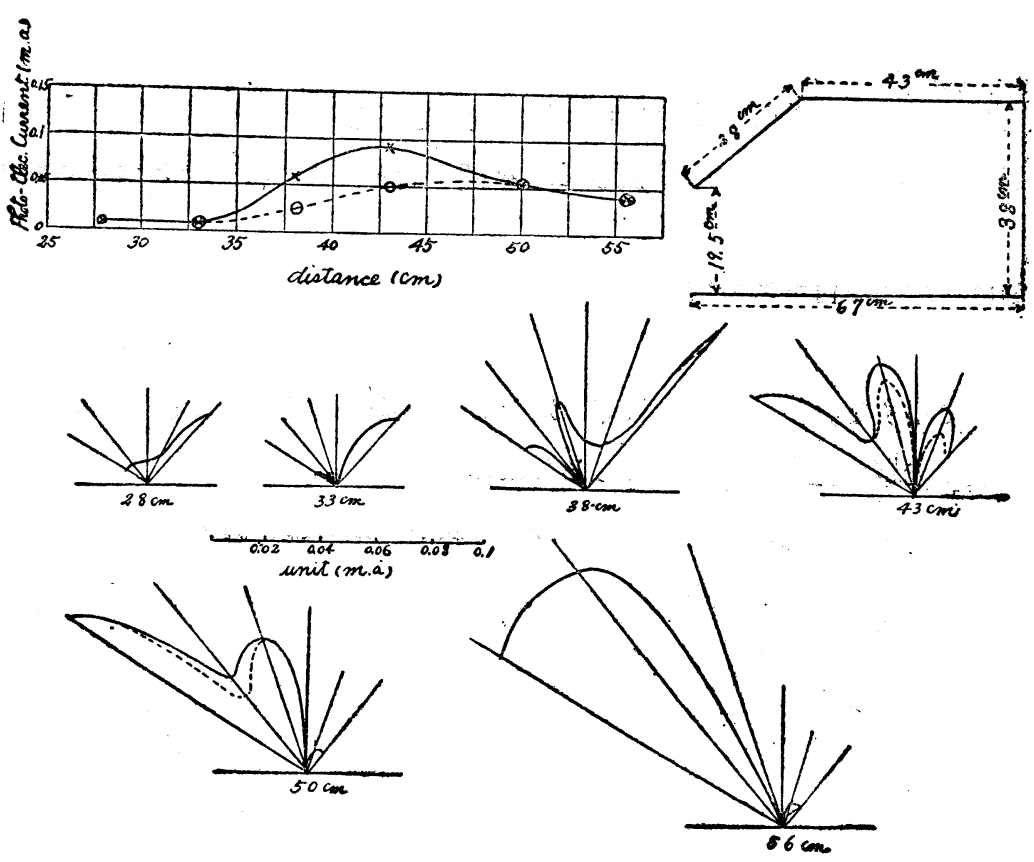

第十 圖 
第四表及び第八圖は, 第八圖に示した如き模型に對して光源を $8 \mathrm{~cm}$ の位置に置をたる場合の 結果を示したものである。

第四表に於て，a は後壁に光を投じたる場合，bはしからざる場合の結果を示したるるのであ る。第八圖の曲線にて實線は $\mathrm{a}$ の場合, 點線は b の場合を示したるるのである。

第九圖は第八圖の場合と同じ模型に對して, 圖の如を位置に $R_{4}$ 及び $R_{3}$ を張りたる場合の曲 線である。

第十圖は圖の如を直線形の場合の測定值を示したるのである。光源の位置は 8 粝である。
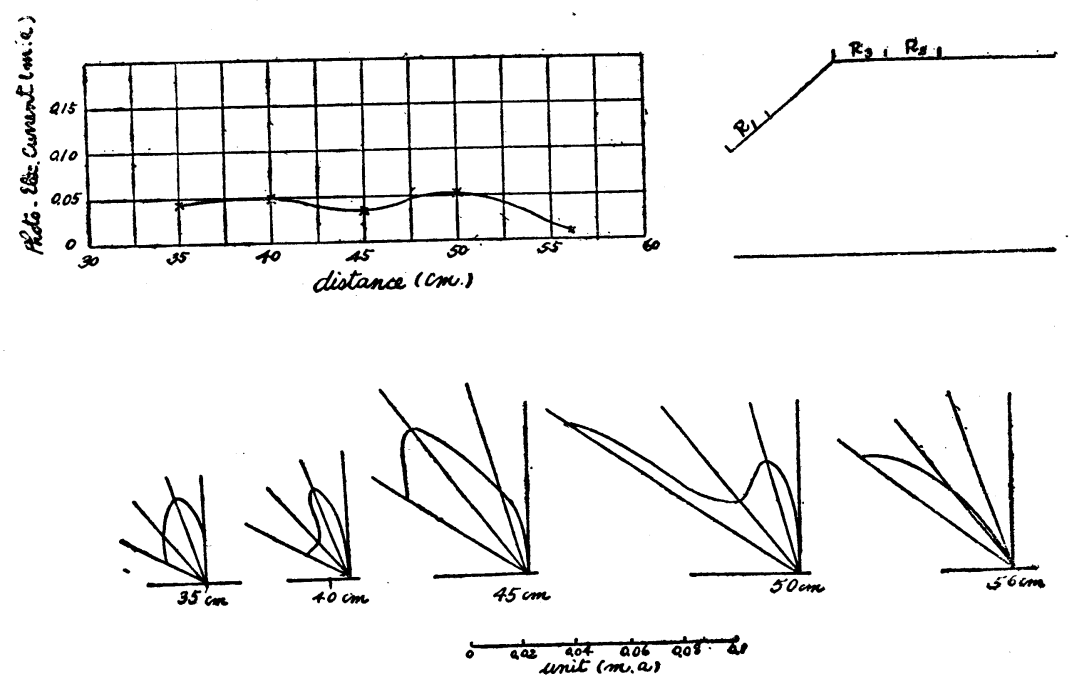

第十一圆

第十一圖は第十圖と同形のものに對して，其の後壁を外し

光源の位置を 20 粝となし, $R_{1} R_{3}$ 及び $R_{2}$ を圖の如き位置に張りたる場合である。

結 言

以上の賽驗は比較的簡單なる模型て對して行つたるのであるが像期以上の好結果を得たるるの である。

倘模型製作に使用する金虽板及び叙料等に對して，相當の研究問題の存する事と思はれる。是 等の諸問題に就て先翌諸兄の御指導が得らるれば幸ひである。

本實驗に對して黑川争三郎教授の有力なる御助言及び終始實驗に努力されたる學生池谷定雄君 に深く感謝の意を呈するbのである。 